\title{
WATER SUPPLY OF WEST AFRICAN TOWNS.
}

\author{
By HENRT REETE, C.M.G.
}

\begin{abstract}
THE question of a pure supply of drinking and potable water is one of the gravest importance to communities in any climate, and especially so uncler a tropical sun, where the arerage temperature of the water fits it ats a medium for the propagation of innumerable species of bacteria and infusoria, some of which are injurious when taken into the human system.

It follows, therefore, that when water is collected for human consumption in the tropics, it is necessary that it should undergo a process of filtration before consumption, and, if possible, it should be protected from air and sunlight during the period which intervenes between its filtration and its consumption. The furtler precaution of boiling may be left out of consideration at present, as that process, although easy as regards individuals or households, is hardly practicable for the supply of a large community.
\end{abstract}

In countries where the natural formation of the land lends itself to the collection of the rainfall into streams, at a sufficient elevation to distribute to the community by gravitation, the filtration is carried out artificially, by the interposition of filter beds, of sufficient capacity, between the source of supply and the consumer.

In many of our African towns, however, this desirable conformation of the surrounding territories does not exist, and in West Africa especially most of the towns are on a sandy coast, or on small islands, near the main land, the soil of which is also sandy.

Free Town is an exception to this rule, and that community rejoic's in :III :mple supply of witer, caught in the valleys of the picturesque range which overhangs the town, and gives its old Spanish name to the colony.

The towns of Bathurst in the colony of Gambia, and Lagos in the colony of that name, follow the rule and are both built upon islands of sandy soil, with no hills or valleys of practical value as a catchment. ground within 100 miles.

The water supply of these towns offered an interesting problem from 
a scientific point of view, and especially so, because the Africans are as childishly careless about the purity of the water they drink, as aljont many other subjects, and they therefore require the protection of the European in this direction, to ensure both their own health, and also, to prevent them from becoming a danger to the community at larere, loy infection of their more careful neighbours. In clealing with the question of a pure watcresuply for tropical towns, it is the supply for the natives which is chicfly indicated as requiring consideration, as the European invariably drinks rain-water from his tanks which is grenerally boiled and filtered before use.

The well water is used for washing, and in many cases for cooking; and in this connection, the European would also profit by an ample supply of pure water for household and for general use.

\section{Tanks.}

The establishment hy science of prevention of maluria, by the extermination of mosquitos, led to a "areful study by Sir William McGregor, the Governor of Lagos, on the question of how to catch rain-water from the roof of a house and comserve it for future use, without offering an ideal breeding place to the insect-pest, which would practically always be within striking distance of its victim.

While every other water surface avilable for breding mosquitos could be done away with, the tank remained a necessary adjunct to the houses of the European in tropical climates, for the storage of rain-water, as a provision for the dry season.

As a practical outcome of Sir William's study every govermment quarter, and many of the merchants' houses in Lagos, have been fitted with tanks, which not only prevent the ingress of dirt from the roofs, after seisons of dusty dry weather, but which also forbicl the ingress of the mosquito to lay its eggs, and, should the eggs be washed down from the roof, the exrress of the insect when developed.

Formerly the iron tank in a tropical sun, filled with pure water, formed the ideal warm-water nursery for the many pests which affect the comfort and endanger the life of the householiler. To-dar, however, the protected tank is another step towards prolonging Europcan life in malarial countries.

The arrangement of the protection consists of -

(a) Wire gauze dome-shaped netting, which closes the head of the down pipe in the eave grutters, the mesh 100 to the square inch. 
(b) An elbow inserted into the down pipe to form a riser for the column of water. The junction of the elbow and down pipe is also protected by wire netting, and in this case a finer gauze is used, 225 to the square inch.

(c) A wash-out clbow at ground level, which resting in a concrete drain serves to carry the weight of the pipe, and carries away the waste water when the flushing process is in action.

The delivery is controlled by a screw (ap) worked by a detachable key.

(d) An outlet or ore-flow pipe from the tank, which is also protected by the finer gauze.

(e) An inspection cover which, fitted like a camp-kettle lid, prevents surface water from entering, and also is insecttight by the nature of its construction.

The working directions are as follows: Before rain and after a dry period the plug at the bottom of the down pipe is removed, so that the washing of the roof is carried to the drain.

When the water runs clear the plug is inserted, and the water slowly rises to the lerel of the top of the elbow between the down pipe and the tank, then it legins to cleliver from the point where the elbow joins the pipe. The floating matter and the scum are on the top of the column of water, while the heavier matter sinks to the bottom. The point of intike to the tank being between these two, the water entering the tank through the wire gauze is comparatively free from rubbish or silt.

Excepting in violent storms, when the water is agitated and the colmun exerts a great pressure on the gauze during delivery, the water enters the tank in a clean state.

When the tank is full and the storm continues, the service tilp is opencel and the old water in the tank, together with sediment, is flushed out, making way for the purer fresh rain-water.

The whole arrangement is simple in worling, effective in purifying the water, and above all perfect in the prevention of mosquito brecding, thus completing the arrangements by which a house can be isolated from mosquito-borne malarial infection.

\section{Wells.}

The conditions under which the natives of Bathurst and Lagos obtained their supply of water formerly are almost too insanitary to be 
describer in detail, and but for the special provisions of a hot sum on a sandy soil causing a rapid process of nitrification, together with the flushing of "everything" by the yearly rains, life would have gradually become impossible in these towns.

The first-named town is situated upon the sandy tongue of the Island of St. Marie, which practically forms the delta of the Gamlia. The town, when the writer was there, was intersecterl ly the heads of two swamps the banks of which became the latrine of the native inhabitants residing on their borclers. The water in the swamps was ticlal, but the filth was deposited in many cases above high-water mark, and the whole area was polluted.

The remainder of the town is built upon the sancly soil averaging about two feet above high-water mark, and slojing generally from the sea beach, which is comparatively high from the piling of the sand by the Atlantic rollers, down to the interior swamps above described.

On this slope the town rests, and the general water supply is obtained ly digging through the sandy top soil, and in the private yards putting two or three barrels down to water level. In the public wells the sides ar'c built, and during my stay the old wells were being gradually replaced by the new model of a self-sinking well, which will be described hereafter.

It will be recognised that the population of Bathurst resides practically on the cover of its own reservoir, the water of which is polluted by the filth of the people and animals, through the swamps above mentionerl, as well as by cesspools which existed in the yards of the natives.

Efforts were being made in 1901 to improve these conditions by reclaiming the swamps in question, and by taking other measures to strengthen the sanitary environments of the town and population against disease.

The conditions of Lagros, a town with ten times the population of Bathurst and similarly situated on a sandy island, are, or were in 1901, practically the same as regards water supply.

We have the sime swamps penetrating the island, with thick population round them. The water for the majority of the population is drawn from the wells which tap the fresh water at or about high-water mark, and, as in Bathurst, the town, with its numerous sources of pollution, is over its own reservoir for water supply.

The wonder is, not that epidemics of sickness occur in these places, but that they occur so seldom.

The ancient Lacustrian had a water supply under similar circumstances, but his lake was infinite compared with the population, and the 
consequent pollution was therefore infinitesimal. In the cases under examination the area of water surface is practically the area of the town, and each resident draws from the water actually under his yard.

It may be of interest to some, who have not studied this particular phase of nature's provision for storage of rain-water, to describe the theory of its antomatic storage.

It is easily understood how fresh water may be extracted from hiogl sand hills, such as the dunes of Holland, from which both Amsterdam and Haarlem draw part of their supply, as this is the natural drainage, similar to a surface drainage into a rivulet or brook from a hill sile, excepting that the drainage takes place altogether below the surface, and the artificial camal which is cut through the dunes play's the part of the brook.

It is not quite so easy of comprehension, howerer, when the whole of the area of an island is at, or nearly at sea level, to account for a storige of fresh water in the simdly soil.

The phenomenom was tirst obserred by the writer many years ago in the islands in the Pacific, where the passing schooner and the canoe filled their water barrels from a sandy shore, or island, with very little trouble in digging. The observation of this led to the establishment of a well on the island of Nuhuloa in Fiji, where a coolie depot was erected to receive the lahores on arrival and departure from the colony, which yielded a good supply of good potable water.

The principles of storilge of fresh water in sandy islands there observed were applied to several other colonies, and in the Gambia and Lagos the same source of supply was found to be in general use.

The factors governing the natural conservation of the fresh water in sand also exposed to saturation by salt water appear to be:-

(a) The size of the grains of sand of which the sea-shore is composed.

(b) The rainfall at the place governing supply.

(c) The rise and fall of the tide affecting the amount held up.

(1) The superior density of salt when compared with fresh water.

If we suppose a porous jar filled with fresh water and standing in a basin of salt water, it may be taken to represent a sand island in midocean.

The rainfall on the sand above high water saturates the sand, equal to filling the porous jar. 

(a).

The amount of water absorbed by the sand and retained depends upon

The regular supply to be obtained depends upon $(b)$ as to the periodic saturation.

The depth of the saturated stratum above low water during dry periods depends upon $(c)$.

The quantity of fresh water held permanently in reserve below low water is due to $(d)$, and this is again influenced by $(a)$ and the presence or absence of loam or mud on the sea-shore, the action of which is to close the pores of the ideal jar.

In order to elucidate the presence of fresh water in the sand below the low-water mark of salt water, we will suppose the jar to hare an impervious bottom representing in nature the finer sands and silts together with the marine plants and organisms which generally form the foundation of a sand island. Owing to the continual washing of the tides and waves during formation the larger particles are separated and sifted to the top, similarly to the particles in a sieve worked by hand or machinery.

In several instances known to the writer, this impervious stratum takes the form of a slimy quicksand, the slime being apparently due to the decomposition of shell-fish and organisms which flourished in warm shallow water, but which died when nature gradually superimposed another bed of sand.

Let us suppose the ideal porous jar to now be filled with fresh water and to be standing in salt water up to its medial line, eraporation goes on above this line, and gravitation forces the fresh water through the pores both above and below the medial line until a bilance of forces is established, and the water inside the jar still remains fresh when the balance is established. The quantity remaining represents the reserve water which remains during the dry periods.

When the balance of power is established, the fresh water and salt water should meet at some point inside the porous material, of which the ideal jar is supposed to be constructed, but owing to the superior density of the salt water, and the consequent superior power of penetration of the fresh, this point is practically the outside film, and in actual practice the presence of seaweed alge and slime on the bed of the sea form an effectuil barrier to the penetration of salt water, so that fresh water may be obtained by digging on the slopes of a beach at low tide.

Another factor which keeps the balance in favour of the inside forces as regards level is the capillary attraction of the water, together with the power of absorption of the sand. These are dependent on (a) and in 
laboratory experiments with the dry sand from the Lagos Water Works water was found to rise to 14 inches by capillarrity, while 100 ounces of the same sand alswrolned $26 \cdot 8$ ounces of water.

It is also owing to appillary attraction, that in places where the ticlal range is low, saly two to thee feet, as in Laygos, the lerel of fresh water is maintained during the period of low water.

In actual practice, the sand is found to be saturated about one foot above high-water mark, and the level of fresh water in a well, under these conditions, during lengthened periods of dry wather, coincides, erenemently speaking, with high-water milrk.

Where the rise and fall of tide is about five to six feet, as in the Gambia, the fresle water level is maintained near to low-water mark, and after lengthened dry periods there is a slight trace of salt in the wells on lower ground, those in the higher banks of sand retaining their freshness, although near to the sea-shore.

With the recurrence of the rany season the island is practically atloat with fresh water, and the wells are refreshed, equivalent to refilling the ideal porous jar.

It will be seen from the foregoing that a beneficent providenec has stored large quantities of fresh water near the salt water in places where it is absolutely necessary to animal life; and that, moreover, owing to the natural filtration that it has undergone in passing through the superincumbent strata of sand, its quality is superior to most river waters, which are subject to pollution both by exposure of surface, and by the populattion residing on the water-sheds.

Having such a source for water supply at hand it behores man to take every necaution on piercing the surface against pollution from any source.

It does not follow that occupation of the surface would necessarily destroy the purity; provided that a sufficient clepth of sand overlies the water, as in the two towns mentioned the surface has been densely populated for many years.

Penetration of the surface, however, for wells and cesspools, as described above, must necessarily poison the reserved water, and were it not for the heivy ammual rainfall in these two places, the water would have become und rinkable and dangerous to animal life.

As to cesspools it is hardly conceivable that successive sanitary authorities should have allowed their existence side by side with the well from which the residents drew their water.

As to wells as formerly constructed, they constituted a danger, only in a less degree, as they were not constructed under supervision, and, 
moreover, in many cases, were so constructed that the washings and filth of the surface returned to the well, while in the absence of any provision for pumping each customer brought his or her dirty or clean bucket and rope for drawing water.

The construction was, moreorer, faulty; inasmuch as the sand which composed the filtering medium nearest to the well was disturbed by digging a large hole in which the well was built, and the outside was then filled in with the disturbed sand, together with brick and other débris, thus practically nullifying the benefits of the naturally deposited sandy formation as a filter.

The rain and surface water, of course, reached the water level in these wells, more readily down the side of the brickwork, and carried with it the slops made by the users of the well in washing their cooking utensils and feet, or in bathing.

In addition to this the structure itself was not impervious, and in many cases the water level was maintained by leakage through the sides.

The remedy to all these evils was found in the Self-sinking Concrete Well, with its pump equipment at such a distance as to forbid pollution from any surface sources.

It may be briefly described as a concrete cylinder, 4 feet in diameter inside, and 5 feet 6 inches on the outside, formed of rings which are 1 foot deep and 9 inches broad, cast in boxes to the proper curve, and rebated concentrically half the breadth. The ring is formed of ten blocks with radial joints, these may be also rebated, or joggled, if desired, in order to make the cylinder watertight at the greater depths.

The bottom ring is formed of blocks with a cutting edge on the outsile made by casting the block with a mitre.

In building, the blocks are talien to the site separately, and a centre bar is driven into the ground on which an arm works on a collar in order to gauge the circle truly in building. Having struck the circle five feet six inches in diameter, the sand or loam is taken out to a depth of about eighteen inches and the ring of cutting blocks truly set in position.

The vertical blocks are then closerl with cement mortar and the ten blocks are grouted up with cement.

The second ring breaks juint or bond and is similarly dealt with and so on until seven or eight courses are built like a columu above ground.

The mason now fixes plumb bols to the inside diameter at right angles, and diers away round the centre bar, continuing digging an inverted cone until the weight of the column exerts its power, and the cutting edge shears vertically, while the mitre throws the sand or loam inwards. 
The process continues of clearing the centre, and gradually the columm sinks to ground level, courses are added each day and allowed to set during the night.

When the cutting edge raches the water level the sinking is automatic, and a bucket is used to take up sand and water combined from the centre, - while the well gradually sinks to the desired deptl.

It may happen that a quicksand is reached, and that therefore it is desirable to stop the well and sustain it in its position by nullifying the effects of the cutting blocks.

This may be done either by extracting them, inserting concrete slabs moler them, or by completing the mitre of the cutting blocks by five rarlial slabs impinging on a concrete block as a centre.

The well then is floating upon the quicksand, and comes to rest permanently with half its bottom area available for supply.

It may be remarker here that by the acloption of this method of penetrating the stratum of filtering media overlooking the water-bearing formation, the former remains undisturbed during the process of sinking, and in fact, is left in a ligher state of compression around the walls of the well than elsewhere. This process results in the prevention of percolation of water indifferently filtered down the outer circumference.

An improvement to these wells was made in Lagos by establishing the pump equipment at a distance of thirty feet from the well, by fencing in the immerliate area around the well, and by covering over the top with an iron roof in addition to an insect-proof gauze cover.

Under these conditions, and given that it had not been previously polluted, the water should arrive at the surface as pure as that caught from a galvanized iron roof into a tank, for it must be remembered that in the tropics, even tank water is subject to adverse influences from dust and bird-deposits on roofs, and unless hermetically sealed is subject to contamination in the tank while awaiting consumption.

Iowerer satisfactory the well described above might be for a comparatively small community, it is evident that even given initial purity a town could not depend upon this source of supply for all its necessities in that direction, and in 1899 , on the initiative of the Governor of Lagos, a scheme was evolved to extract larger quantities of water, from an area comparatively sparsely occupied, to the east of the town and on the Island of Iuagos.

After examination and consultation with Mr. Osbert Chadwick, C.M.G., the Consulting Engineer to the Colonial Office, it was found that the area

vol, xxr. PART Ir. 
available was insufficient for the supply of the daily minimum, and that, moreover, the schene did not admit of extension in the future.

However, so much was done that it prepared the war for the larger scheme which is now in progress, and of which the final report is attached to this paper for reference.

The details given may be of use in future enquiries as to the possi- . bility of a water supply from similar sources.

The whole scheme has received the approval of the Secretary of State for the Colonies, and the design for collection, pumping, and transmission across the lagoon to Lagos is now being formulated.

The new catchment ground lies on the main land opposite to Lagos Island, and it will be nocessary to carry the supply across the harhour to the service reservoir in the town.

The line chosen intersects two chamnels navigable for large steamers, and will be two thirds of a mile in length from shore to shore.

On reference to the report it will be seen that the sand immediately below the water-bcaring strata is extremely fine, and is, moreover, mixed with a species of China rlay forming with it a quicksand.

In orcler to tap the largest possible quantity of the reserve water, the collecting pipes will be litid on this quicksand formation, and the lifficulty of letting the water in and keeping the quicksand out will be met by floating the collecting chamed on timler planking where it touches the quicksand.

The collectinge channels will he latel dewn in the stratum of waterbearing sand, the bottom luoing about five feot helow high-water level in the lagoon or harlourr.

The surface will only he disturlerl where necessiry to this work in meler to retain the gresit mass of filtering matter intact. Where disturbed the ground will be carefully mirle up with selected material, als nearly ats possible in the layers as taken out of the trenche's, and well rammed in order to prevent water entering the collecting channels which has not. undergone effective filtratious.

The collecting chamels will rum along the platean, following a contour line on both slopes, so that the water entering will le taken from the central part when the platean is saturated with rain, and will only draw on the reserve below high-water level during extrenely dry periods.

The collecting chamels will deliver into a receiving tank, from which the water will be pumped up a suflicient height to deliver into a service reservoir in Lagos, which will have a minimum head of tifty feet orer any portion of the town, and about seventy fect over lagoon level. 
The vialuct to carry the pijes arross the harbour will he on scress piles above high water, acruss the shallower parts of the langom, with inverted syphons at the navigable channels. The syphons will have guard towers at ciach cund, cilly'ying electric lamps at night.

Two sites have been chosen for service reservoirs, whith will command the whole of the town, for distribution to loonses and stantpipen, wateringe streets and Hushing street clammels.

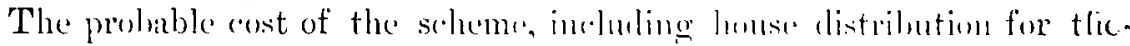
town, where possible, and st:und pipe listribution to all native putarters and

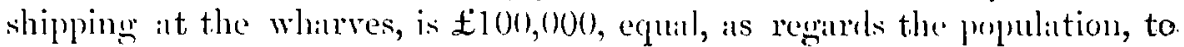
al capital experuliture of $\mathbf{f} 2$ pere hearl.

A water rate of 5 per cent., ar $2 s$ per hear per :mmum, wonld be required from the native jopulation for standpipe distribution and samitary purposes, which would be sufficient to prey interest an the calpital, and provide a sinking fund, while the lunse to house distribution, "wn a higher rate or ly meter, would pay working exprenses, upkere of pliant, etc. With these provisions the waterworks should become it reproductive pullic work, and besiles the incalenlable benetit to health and life that it would bestow upon the proulation at Latans, in time if will contribute at considerable sun ammall!" to the levemen of the "olomy.

Lages lans now its water sulpy well in view, and it is tw he hoped that a similar scheme will be applied to the Gambia, and other columies or towns that still await the help of sitnitary science, louth for the preseriattion of human life and for their progeress towards civilization.

It is by these amb other scientitic works that we matrk step, lye step, the progress of the dark continent towards the enlighlowenent of European nations. The greatest teacher that mankind has aver known has said, "By their works ye shall know them ;" and in the humble conscientious: opinion of the writer, it is ly these work that Eunpe:m nitions ("ins justify their interference with the lands and lives of the Africans. and justify their presence there in the sight of the Creator of the mirerse. 